\title{
Sustainability in chronic disease prevention: lessons from the Salud al Paso program in Ecuador*
}

\author{
Fernando Sacoto, ${ }^{1}$ Irene Torres, ${ }^{2}$ and Daniel F. López-Cevallos ${ }^{3}$
}

Suggested citation Sacoto F, Torres I, López-Cevallos DF. Sustainability in chronic disease prevention: lessons from the Salud al Paso program in Ecuador. Rev Panam Salud Publica. 2021;45:e30. https://doi.org/10.26633/RPSP.2021.30

ABSTRACT

This study analyzes the conditions and possibilities of sustainability of the Salud al Paso program of the Metropolitan Health Secretariat of the Municipality of Quito, Ecuador, as an example for similar initiatives, in the context of the changes made by the new administration in May 2019. The analysis of the implementation of this initiative, focused on the prevention of noncommunicable diseases (NCDs), was based on the program's user database, the information gathered on the perspectives of operational staff, knowledge of the program, and the opinion of local leaders and opinion leaders of the Quito Metropolitan District, as well as official information. Based on this data, the study identified factors that could have facilitated or hindered its sustainability and documented the rationale to suspend the on-demand activities included in the program and limit activities to the care of populations under municipal responsibility (day-care centers, schools and colleges, markets, elder care programs, and employees) and patients with identified cardiometabolic risk. The insufficient institutionalization of the program, conceived as a project with an insufficient vision of its sustainability in time, was mentioned as a possible obstacle by leaders and operational staff. The growing prevalence of NCDs requires initiatives for their prevention, which must be institutionalized to ensure their continuity and overcome eventual changes of government. In addition, future interventions similar to Salud al Paso should establish better sectoral coordination articulation, especially with the Ministry of Public Health and other service networks.

Keywords Public policy; preventive health services; noncommunicable diseases; health management; Ecuador.

In Ecuador, approximately $65 \%$ of the population over the age of 19 is overweight or obese-risk factors for noncommunicable diseases (NCDs)—, with a direct and indirect expense equivalent to $4.3 \%$ of the annual gross domestic product (GDP) (1). In parallel with the private health system, the public system operates in a fragmented and centralized manner in two sectors: the different social security programs and the Ministry of Public Health. The predominant national cure-focused model limits preventive approaches to address the increase in NCDs; health policies are stagnant or formulated at the discretion of the current government, with no medium- or long-term vision for ensuring their sustainability (2). Instead, they are designed to increase the visibility of politicians and their parties and to generate short-term revenue $(3,4)$.

The Metropolitan District of Quito (DMQ), with nearly 2.5 million inhabitants, is experiencing a significant increase in NCDs (5), especially diabetes and hypertension, which are tied to malnutrition, a sedentary lifestyle, overweight, and obesity (6). In addition to three health municipal units with limited on-demand healthcare services, the municipality of the DMQ had promotional preventive programs for the "captive" population under municipal responsibility, which accounts for less than 5\% of Quito's population. Metropolitan Ordinance No. 494 of 2014 called for the implementation of promotional,

\footnotetext{
* Official English translation from the original Spanish manuscript made by the Pan American Health Organization. In case of discrepancy, the original version shall prevail. Access to original manuscript: https://doi.org/10.26633/ RPSP.2020.113
}

\footnotetext{
1 Ecuadorian Society of Public Health, Quito, Ecuador

2 Octaedro Foundation, Quito, Ecuador. $\triangle$ Irene Torres, irene.torres@octaedro. edu.ec

3 Oregon State University, Oregon, United States of America.
} 
prevention, and surveillance activities throughout the DMQ, so the 10-Year Quito Health Plan for 2015-2025 set the goal of promoting the adoption of healthy lifestyles to help prevent or control NCDs (7). In this context, the Salud al Paso program (SAP) was created in May 2015 (8).

This study analyzes the conditions and possibilities for the sustainability of the SAP program in the Metropolitan Health Secretariat of Quito, Ecuador, in light of the changes made by the new government in May 2019. In particular, we examine the factors that may have influenced the decision made by the new authorities to suspend the program, as well as needs for improvement in the event of similar future initiatives.

\section{MATERIALS AND METHODS}

\section{Study design and sample}

The study is part of the initiative Improving Program Implementation through Embedded Research (iPIER) developed by the Alliance for Health Policies and Systems Research in collaboration with the Pan American Health Organization (PAHO). This initiative places program implementers in research centers in order to understand barriers to implementation, which will facilitate the identification of solutions and contribute to the effectiveness of health programs and policies (9).

A descriptive study was conducted that focused on the design and execution of the SAP program by the DMQ Health Secretariat (2), the characteristics of users and the perceptions of operational staff, local leaders, and opinion leaders regarding the program. Using the guide of Peters et al. (10) for analyzing health policy implementation, the applicable outcome variables and potential needs for improvement were studied.

The perception of health workers regarding the SAP program was obtained based on the opinions of 69 of the 76 professional nutritionists who worked directly in screening, user education on NCD prevention, adoption of healthy lifestyles, and improvement of nutritional risk in 25 health care units.

In addition, 90 local leaders selected on the basis of their representation of beneficiary sectors (rural parish boards, municipal educational institutions, municipal markets, neighborhood community leaders) and opinion leaders (academia, social and health management, journalism, politics, local authorities and social actors) also participated.

\section{Data collection}

Database. The anonymized database of SAP users was accessed under a confidentiality agreement with the Health Secretariat. This database covering the period from April 2015 to May 2019 included 525252 people (1 058880 visits), of which 444990 (934 525 visits) were over the age of 18 years.

Documentation. The analyzed information includes documents issued by the Health Secretariat of the DMQ Municipality: legal frameworks, standards, the 10-Year Health Plan for the DMQ Municipality, and the SAP procedures manual (11), as well as technical, operational, and financial management reports, official communications of the new administration regarding the program, and the Health Secretariat's "Proposal to Restructure the SAP" of June 2019.
Operational staff interviews. A self-administered structured interview was electronically sent to operational staff of the SAP program as a virtual form. After receiving instructions and signing an informed consent, their responses were returned in an anonymous and confidential manner. This survey included open-ended and closed questions on working conditions, perceptions, and perspectives of the program, as well as their own performance.

Leader surveys. The survey of local and opinion leaders was administered by a member of the research team, who guided the participants. Some participants responded on their own using a virtual form, while others were surveyed by phone. Instructions and the informed consent form were provided prior to the questions. It was decided to conduct a survey instead of an interview in order to reach the most participants possible, since an initial contact showed that participants were more willing to take a survey that included open-ended and closed questions aimed at assessing their knowledge of the SAP program and NCDs, and their position and opinion regarding the program's sustainability.

Feedback workshop. After the surveys, a feedback workshop was attended by 69 professionals: 62 direct care nutritionists, five supervisors, and two logistics people.

The participants shared their perspectives on organizational issues, user opinions, and the program's future. The conversations were recorded with their consent and written contributions were compiled, transcribed, and stored in a protected file that could only be accessed by the investigators.

Processing and analysis. The telephone surveys of opinion makers were transcribed word-for-word and compiled along with responses sent virtually. The quantitative responses from the two surveys were disaggregated and tabulated by question, and the qualitative responses were compiled by question and initially coded in a matrix in open and inductive manner.

The quantitative data in the database were used for a descriptive statistical analysis of users, care, and intervention plans. The text of the qualitative questions was coded and compiled by similarity based on thematic categories, and their frequency was tabulated so as to identify the most common opinions shared by participants.

The quantitative and qualitative data were reviewed based on the recommendations of Peters et al. (10). This being an innovative intervention, the analysis focused on topics such as acceptability, adoption, sense of ownership, and feasibility, although coverage and costs were also included. The quantitative data in the database and the information provided by the new Health Secretariat authorities were analytically correlated, and also linked with the qualitative data from the respective surveys, documenting the reasoning and grounds for the institutional decision made on the future of the SAP program.

Feedback with the new authorities. On 12 May 2019 the preliminary results of the study were analyzed with the new technical directors of the Health Secretariat; at an expanded meeting held on 10 September 2019, various criteria and documents were received which the authorities used to justify the decision to suspend the SAP program. 


\section{Ethical aspects}

The participants were informed of their rights as participants in writing or verbally, before giving their consent. The transcripts of the workshops do not contain their names and the surveys of leaders were identified with a numerical code. The study was approved by the Ethics Review Committee of the Pan American Health Organization (PAHOERC-2019-01-0003) and by the Bioethics Committee for Human Subjects Research of the International University of Ecuador (CEU-082-19).

\section{RESULTS}

Table 1 shows a summary of the results of each variable and its implementation outcomes, based on the model of Peters et al. (10).

\section{Coverage}

The country's official statistics records were obtained from the National Statistics and Census Institute (INEC). They do not include nutritional prevention activities, such as those offered by SAP, since only prevention consultations with physicians, obstetricians, psychologists, and nursing staff and the coverage of preventive dental services were recorded (12).

Table 2 shows the coverage results obtained by the SAP program during the time it was in effect (April 2015 - May 2019). Three indicators were prepared: one general indicator of the total population in the DMQ, and two specific indicators: total population over 18 years of age, and users over 18 years of age living in the DMQ.

The SAP program (2015 - 2019) covered $21.6 \%$ of people over 18 years of age in the DMQ and intended to reach a target of $40 \%$ coverage by 2025 . Of the total number of people at risk of NCDs who started an intervention plan, the SAP included the population between 18 and 64 years of age. A global analysis of cohorts monitored semiannually between April 2015 and September 2018 identified 233753 overweight or obese users over 18 years of age that initiated the intervention plan, 52565 $(22.5 \%)$ of whom were subsequently seen more than one time.

\section{Costs}

The total budget accrued between April 2015 and December 2018 according to budget reports of the Finance Department of the DMQ Municipality was US\$ 9880 168. During this period, the unit cost per person seen $(n=525252)$ was US\$ 18.81, and US\$ 9.33 per visit $(n=1058880)$.

\section{Acceptability}

The operational staff were consulted regarding their view of the acceptability of the program. They said the program was innovative and current, was located in places convenient for the population, and was promoted in public activities such as fairs and other events, so that, in their opinion, it was easy to access and did not impose a financial burden (free of cost). They also mentioned personalized care and the provision of educational materials that encouraged the population to adopt healthy practices.

Among restrictions, they pointed out that not all users were seen long enough to perform a complete assessment, which could adversely affect people at nutritional risk who require more support. A lack of waiting areas and lack of privacy was also reported.

Furthermore, the majority (85\%) of the 32 consulted leaders who received care in the program rated their experience as excellent or very good, while the remaining $15 \%$ rated it as good.

\section{Adoption}

The adoption variable was defined as the "intention, initial decision, or action taken to try to employ an intervention" (10). The study analyzed the gradation of the program; a reduction was observed in the number of people seen per year with respect to the initial period from April to December 2015. As of May 2019, the SAP program served 444990 people over 18 years of age (Table 3), out of an estimated population of 1728717 in 2019 (13).

Although there was a decline in the number of people served, the number of visits per user increased (Table 2). Services were

TABLE 1. Variables and implementation outcomes, based on Peters et al. (10), Salud al Paso program, Quito, 2015 - 2019

\begin{tabular}{|c|c|}
\hline Variable & Implementation Outcomes \\
\hline Coverage & $\begin{array}{l}\text { - The program reached } 21.6 \% \text { of people over } 18 \text { years of age } \\
\text { - Target coverage by } 2025: 40 \%\end{array}$ \\
\hline Cost & $\begin{array}{l}\text { - Total cost = } 9880168.88 \text { United States dollars (US\$) } \\
\text { - Cost per person seen }(n=525,252): \text { US\$18.81 } \\
\text { - Cost per visit }(n=1058880): \text { US\$ } 9.33\end{array}$ \\
\hline Acceptability & $\begin{array}{l}\text { - } 85 \% \text { of consulted leaders who received care rated their experience as excellent or very good } \\
\text { - A lack of waiting areas and lack of privacy during visits was reported }\end{array}$ \\
\hline Adoption & $\begin{array}{l}\text { - As of May 2019, the SAP program saw } 444990 \text { people over } 18 \text { years of age } \\
\text { - There was a reduction in the number of people seen per year, compared to the initial period from April to December } 2015\end{array}$ \\
\hline Appropriateness & $\begin{array}{l}\text { - } 93 \% \text { of the operational staff consulted }(n=64) \text { said that the SAP is a pertinent preventive strategy } \\
\text { - There is a need for the nutritional monitoring of users, as well as for effective medical referral mechanisms }\end{array}$ \\
\hline Feasibility & $\begin{array}{l}\text { - Regulatory endorsement of Ordinance No. } 0494 \text { of } 2014 \\
\text { - Growing citizen concern over the increase in noncommunicable diseases (NCDs) and their risk factors }\end{array}$ \\
\hline Sustainability & $\begin{array}{l}\text { - The program as designed did not achieve sustainability in the Municipality of Quito, since the new authorities decided to suspend it } \\
\text { and refocus on the prevention of NCDs }\end{array}$ \\
\hline
\end{tabular}


TABLE 2. Care provided, number of visits, and coverage of the Salud al Paso program, Quito, April 2015 - May 2019

\begin{tabular}{lccc}
\multicolumn{1}{c}{ Care provided } & $\begin{array}{c}\text { Number of } \\
\text { visits }\end{array}$ & $\begin{array}{c}\text { Population in } \\
\text { the DMQ 2019 }\end{array}$ & Coverage (\%) \\
$\begin{array}{lccc}\text { Total care provided to children over } \\
\text { age } 2\end{array}$ & 525252 & 2672429 & 19.65 \\
$\begin{array}{l}\text { Total care provided to people over } \\
\text { age } 18\end{array}$ & 444990 & 1728717 & 25.74 \\
$\begin{array}{l}\text { Total care provided to people over } \\
\text { age } 18 \text { living in the DMQ }\end{array}$ & 372852 & 1728717 & 21.57 \\
\hline
\end{tabular}

DMQ, Municipal District of Quito.

a The number of visits by people over 18 years of age is extracted from the total of 525,252 visits. The number visits by residents in the DMQ over 18 years of age is extracted from the total number of visits by people over 18 years of age, and the remaining 72,138 not accounted for are people over 18 years of age who do not live in the DMQ but received care.

Source:Produced by authors based on the Salud al Paso program information system and population projection of the City Institute, Municipality of the DMQ (13).

expanded, from initially only including nutritional screening and general advice on healthy habits, to a risk criteria approach in June 2016 that included personalized counseling and monitoring of people considered low risk, who began a six-month intervention plan with at least four visits. Higher risk people were referred for cardiometabolic care provided by Municipal Health Units or other health services (11).

The adoption variable could also be regarded as a sense of "ownership" of the program by SAP operational staff. This aspect was addressed by asking whether they "regularly contributed ideas and opinions for improving the program." Of all SAP operational staff, $88 \%(n=61)$ reported that they did, while 29 professionals felt that their contributions were taken into account, and 14 thought that they were not. The remaining 18 individuals appeared to be neutral.

Along these lines, in surveys and the feedback workshop, the suggestions on improvement covered two areas: internal, with improvements in operational planning; and external, with possible measures to increase coverage and obtain higher rates of user return. The participants suggest increasing the number of points of care, especially rotational units that are open on weekends, and improving communications and information records. In terms of SAP human resources, they feel it is necessary to improve the rotation of shifts and schedules, encourage staff to update their knowledge, improve the work environment, and prevent and resolve occupational risks.

To improve user care, coverage, and return, they recommend increasing publicity, disseminating and communicating information about the program, holding more SAP-related health promotion events, creating waiting areas, establishing partnerships with local governments, community leaders, and social actors, companies, and institutions, and promoting greater coordination with territorial administrations (the municipality of Quito and the health system).

\section{Appropriateness}

Regarding the relevance of SAP as an appropriate preventive strategy, $93 \%$ of the operational staff $(n=64)$ agreed that it was, rating the outcomes as excellent or very good; only $7 \%(n=5)$ said they were good. Nevertheless, they recommended timelier monitoring of progress or setbacks in users' nutritional risk, as well as effective medical referral systems, as required, with improvements in access and monitoring in rural areas.
TABLE 3. Adults served and number of visits under the Salud al Paso program, Quito, April 2015-May 2019

\begin{tabular}{lccc}
\multicolumn{1}{c}{ Period } & People served & Visits & Visits per person \\
April-December 2015 & 136985 & 192792 & 1.4 \\
2016 & 123787 & 273881 & 2.2 \\
2017 & 79274 & 190996 & 2.4 \\
2018 & 70149 & 183505 & 2.6 \\
January-May 2019 & 34885 & 93351 & 2.6 \\
Total & 444990 & 934525 & 2.1
\end{tabular}

\section{Feasibility}

The feasibility variable is defined by Peters et al. (10) as the "extent to which an intervention can be carried out in a particular environment or organization." The SAP program is endorsed in Ordinance No. 0494 of 2014, which was still in effect as of the date of this study. Institutional feasibility in the municipality of the DMQ is confirmed by the existence of organizational and financial resources included in the annual budgets of the Health Secretariat, the entity that by law should "lead comprehensive health management in the municipality...". Institutional feasibility is, in turn, supported by constitutional mandates with a similar focus (14).

Growing public concern about the increase in NCDs and their risk factors, global evidence of the urgent need to prevent the serious social and economic impact of these diseases (15), and successful cases of similar interventions in other countries $(16,17)$ all lend feasibility to programs such as SAP. In the study, $99 \%$ of the leaders interviewed were aware that "obesity and excess weight contribute to diabetes, hypertension, cancer, and other noncommunicable diseases," and 71\% reported that there were people with hypertension, diabetes, or cancer in their own family circles.

In any case, well-supported initiatives such as the SAP could be even more feasible in the context of solid health institutions that position government health policies. In the absence of such a context, the authorities of the moment may or may not, at their discretion, decide to support these initiatives. Indeed, the greatest identified risk or obstacle to the sustainability of the SAP was "support from the authorities" $(n=24)$, followed by "funding" $(n=23)$.

\section{Sustainability}

Sustainability is defined as the "degree to which an intervention is maintained or is institutionalized in a given environment." The SAP program, as such, did not achieve sustainability in the municipality of Quito, since the new authorities decided to suspend its execution and instead refocus the original NCD prevention strategy (i.e., the program to "promote the adoption of healthy lifestyles in the Metropolitan District of Quito" and the program for timely detection and management of noncommunicable chronic disease risks in the population over 2 years of age in the DMQ [ $n=2672429]$ ) (Table 4). The new administration decided to "intervene in the population of the municipality through screening to identify metabolic risk factors in order to promote healthy lifestyles, prevent noncommunicable chronic diseases, and treat people 
TABLE 4. Changes in the Salud al Paso program, Metropolitan District of Quito (DMQ), May 2019

\begin{tabular}{|c|c|c|}
\hline & Up to April 2019 & Since May 2019 \\
\hline Scope & $\begin{array}{l}\text { Promotion of healthy lifestyles in the DMQ; timely detection and } \\
\text { management of NCD risks. Referral of high-risk individuals to } \\
\text { municipal health units (UMS) or other medical services }\end{array}$ & $\begin{array}{l}\text { Targeted screening of the population to identify risk factors, } \\
\text { promotion of healthy lifestyles, prevention of NCDs, and treatment of } \\
\text { at-risk individuals }\end{array}$ \\
\hline $\begin{array}{l}\text { Target } \\
\text { population }\end{array}$ & People over the age of 2 living in the DMQ: 2672429 & $\begin{array}{l}\text { Municipal programs and social services population. } \\
\text { Childhood Development Centers: } 10860 \\
\text { Students: } 20246 \\
\text { Market merchants: } 11626 \\
\text { Older adults: } 10659 \\
\text { Municipal employees: } 6830 \\
\text { Total: } 60221 \\
\text { Patients with identified cardiometabolic risk who are seen at a UMS } \\
\text { should be added }\end{array}$ \\
\hline Strategy & $\begin{array}{l}\text { On-demand care at fixed and semifixed points and mobile units } \\
\text { spread throughout the DMQ and care of the municipal programs and } \\
\text { social services population }\end{array}$ & $\begin{array}{l}\text { Suspension of on-demand care; focus on captive population of } \\
\text { municipal programs and social services }\end{array}$ \\
\hline Service points & $\begin{array}{l}10 \text { fixed units, four semifixed, and } 11 \text { mobile units up to the time the } \\
\text { program was suspended } \\
\text { Sites and spaces where municipal programs and social services } \\
\text { operate and three UMS }\end{array}$ & $\begin{array}{l}\text { Closure of fixed, semifixed and mobile units as of July } 2019 \\
\text { Care at sites and spaces where municipal programs and social } \\
\text { services operate and three UMS }\end{array}$ \\
\hline Technical operational staff & $\begin{array}{l}76 \text { nutritionists to provide screening and prevention services } \\
\text { (nutritional counseling) }\end{array}$ & 31 nutritionists to conduct risk assessment and screening activities \\
\hline
\end{tabular}

DMQ, Metropolitan District of Quito; NCDs, noncommunicable diseases; UMS, municipal health units.

Source: Produced by authors based on data in the Salud al Paso program information system.

at risk." (18) This meant that only 60221 people would be covered, in addition to patients identified as having cardiometabolic risk (Table 4).

\section{DISCUSSION}

This study analyzes the conditions and possibilities for the sustainability of the Salud al Paso program of the Metropolitan Health Secretariat of the Municipality of Quito, following the change in leadership in May 2019. In the context of the country's weak health institutions (19), the decision made by the new municipal administration to suspend the program took into consideration the limited capacity for public uptake, as illustrated by the low level of willingness $(27 \%)(n=24)$ of the leaders interviewed to publicly express their support. Another influencing factor may have been limited knowledge about the program among the heads of rural local governments ( 8 of 17 in this study) who, despite their political influence, had little contact with the SAP (only 3 of 17 reported having requested care under the program). Furthermore, it is possible that the second most common way that leaders learned about the programthrough promotion, publicity, and news from the municipal authorities (29\%)- may have led them to identify the SAP with the previous municipal government's policies.

The insufficient institutionalization of the program-which was conceived as a project with an insufficient vision of its sustainability over time-contributed to the fact that after the municipal authorities in Quito were removed on 15 May 2019, the new mayor announced his decision to suspend the SAP program under its original scope. Among the changes introduced (Table 4), the most important were to: stop considering the target population in the DMQ when the rates of overweight and obesity (risk factors for NCDs) exceed $60 \%$ of people between the ages of 20 and 59 (6); and change the promotional and preventive emphasis of the SAP to a curative approach instead, which has limited effectiveness against NCDs (7).
The lack of official records on preventive nutritional activities (a pending task in Ecuador) may be explained by the lack of initiatives such as Salud al Paso which, had it continued, could have created a need to add such records. But it could also be interpreted as a shortcoming because coordination with the national regulatory agency (the Ministry of Public Health) was not implemented when the program was launched. In fact, it was only toward the end of 2018 that a general agreement was signed between the municipality and the respective territorial agency of the MPH (20).

On the other hand, the observed decrease in activity could be due to the fact that the demand at fixed points of care was "exhausted"; so there should have been a plan to replenish users, without ignoring the importance of monitoring people at nutritional risk. In this and other areas, it would have been extremely valuable to hear user opinions. Because these were not obtained due to logistical or financial problems, the analysis was restricted to secondary information. An additional limitation is the lack of a study on the program's budgetary impact.

In the context of the global impact of the COVID-19 pandemic, as of the date of the most recent revision of this study (27 July 2020), and in the midst of major information gaps and significant difficulties in the timely detection of suspected cases, isolation, and control (21), the DMQ had the highest number of confirmed cases in Ecuador: 12561 (surpassing Guayaquil, with 11823 cases) (22). Had the SAP program continued, its installed capacity of 25 fixed and mobile units in the DMQ, properly adapted, would have been crucial for testing, case and contact tracing, provision of information, and social protection measures.

\section{Conclusions}

The growing prevalence of NCDs, with the resulting morbidity and mortality rates in the $\mathrm{DMQ}$, requires initiatives and innovations aimed at NCD prevention. These should be 
institutionalized to ensure their continuity. This is especially challenging during changes of government; indeed, the SAP program implemented between April 2015 and June 2019 was limited in scope by the new municipal government.

In this context, it is important to reflect on how similar initiatives could be sustained in the future. To this end, similar regional initiatives may consider the following lessons learned:

- Include a research component from the start, documenting evidence on the intervention's outcomes and challenges in order to make changes and improvements and generate knowledge.

- Implement strategies for monitoring by program users to improve adherence to interventions and adoption of the program.

- Besides the legitimacy that governments are able to give their initiatives, when communicating about services, especially social services and their outcomes, it is important to stress technical evidence that helps ensure sustainability.

- The continuity of a program involves ensuring the loyalty of its human talent through professional development strategies, including job stability mechanisms linked to performance evaluations.

- Improve ways to involve and serve rural communities so that they will use screening and nutritional counseling services.

- Ensure coordination with other health institutions, especially the national Ministry of Public Health and service networks.
The data on costs and coverage, as well as the responses of community providers and leaders, demonstrate that continuation of the Salud al Paso program, with appropriate adjustments, could have been beneficial to the population.

Authors' contributions. IT and FS designed the original study, collected, analyzed, and interpreted data, and wrote and published the manuscript. DLC contributed to the analysis and interpretation of data, and the drafting and editing of the manuscript. All authors reviewed and approved the final version.

Acknowledgements. The study received technical support from the National Public Health Institute of Mexico.

Financing. The study was financed by the Pan American Health Organization, which did not participate in the study design, data collection and analysis, the decision to publish this study, or preparation of the manuscript.

Conflict of interests. FS served as technical advisor to the Health Secretariat of the Municipality of Quito, with no direct links to the management of the Salud al Paso program. IT and DLC declare no conflict of interests.

Disclaimer. Authors hold sole responsibility for the views expressed in the manuscript, which may not necessarily reflect the opinion or policy of the RPSP/PAJPH and/or PAHO.

\section{REFERENCES}

1. Fernández A, Martínez R. The cost of the double burden of malnutrition: social and economic impact. Summary of the pilot study in Chile, Ecuador and Mexico. UN Economic Commission for Latin America and the Caribbean (ECLAC). 2017. Available at: https:// www.wfp.org/publications /2017-cost-double-burden-malnutrition-social-and-economic-impact

2. Walugembe DR, Sibbald S, Le Ber MJ, Kothari A. Sustainability of public health interventions: where are the gaps? Health Research Policy and Systems. 2019;17(1):8.

3. Hurtado O. Ecuador entre dos siglos. Bogotá: Debate; 2017.

4. Campos-Herrera G, de Reguero SU. Populism in Latin America: past, present, and future. Lat Am Polit Soc. 2019;61(1):148-59.

5. Secretaría Metropolitana de Salud. Diagnóstico de Salud - Distrito Metropolitano de Quito. Quito: Alcaldía del Distrito Metropolitano de Quito; 2017.

6. Secretaría Metropolitana de Salud. Plan Decenal de Salud 20152025. Quito: Alcaldía del Distrito Metropolitano de Quito; 2015.

7. Berán D, Pedersen HB, Robertson J. Noncommunicable diseases, access to essential medicines and universal health coverage. Glob Health Action. 2019;12(1):1670014.

8. Roldós MI, Hopenhayn C, Sacoto F, Bustamante K. Developing local health policy: Profiling needs and opportunities in the Municipality of Quito, Ecuador. J Public Health Pol. 2017;38(2): 221-33.

9. Langlois EV, Mancuso A, Elias V, Reveiz L. Embedding implementation research to enhance health policy and systems: a multi-country analysis from ten settings in Latin America and the Caribbean. Health Res Policy Sy. 2019;17(1):85.

10. Peters DH, Tran NT, Adam T. Implementation Research in Health: A Practical Guide. Geneva: Alliance for Health Policy and Systems Research, World Health Organization; 2014.
11. Jarrín E, Carrillo D, Suárez E, Villalba J. Manual de procedimientos para detección y manejo de factores de riesgo de ECNT y malnutrición. Quito: Secretaría de Salud - Municipio del Distrito Metropolitano de Quito; 2016.

12. Instituto Nacional de Estadística y Censo. Registro estadístico de actividades y recursos de salud. Documento metodológico. 2018. Available at: https://www.ecuadorencifras.gob.ec/documentos/ webinec/Estadisticas_Sociales/Recursos_Actividades_de_Salud/ RAS_2018/Metodologia\%20_RAS_\%202018.pdf

13. Instituto de la Ciudad. Proyecciones poblacionales del Distrito Metropolitano de Quito. Quito: Municipio del Distrito Metropolitano de Quito; 2013.

14. Constitución del Ecuador. Tít. VII, Art. 360. 2008. Available at: https://www.asambleanacional.gob.ec/sites/default/files/documents/old/constitucion_de_bolsillo.pdf

15. Legetic BE, Medici AE, Hernández-Ávila ME, Alleyne GAOE, Hennis AE. Economic Dimensions of Non-Communicable Diseases in Latin America and the Caribbean. Washington D.C.: PAHO; 2017.

16. Elorriaga N, Garay OU, Belizán M, González VB, Rossi ML, Chaparro M, et al. Evaluación del impacto sanitario del Programa Estaciones Saludables en la Ciudad Autónoma de Buenos Aires, Argentina. Rev Panam Salud Publica. 2018;42:e150.

17. Joshi R, Alim M, Kengne AP, Jan S, Maulik PK, Peiris D, et al. Task shifting for non-communicable disease management in low and middle income countries-a systematic review. PloS One. 2014;9(8): e103754.

18. Municipio del Distrito Metropolitano de Quito. Propuesta de Reestructuración del Proyecto Salud Al Paso. Quito: Secretaría de Salud - Dirección Metropolitana de Promoción, Prevención y Vigilancia de la Salud; 2019.

19. Torres I, López-Cevallos DF. Institutional challenges to achieving health equity in Ecuador. The Lancet Global Health. 2018;6(8): e832-e3. 
20. Ministerio de Salud Pública del Ecuador-Municipio del Distrito Metropolitano de Quito. Convenio de cooperación para la prestación de servicios de salud entre el Ministerio de Salud Pública a través de la Coordinación Zonal 9-Salud y el Municipio del Distrito Metropolitano de Quito. Memorando Nro. MSP-CZ9-2018-14245. 2018.

21. Torres I, López-Cevallos DF, Sacoto F. Elites can take care of themselves - Comment on "COVID-19: the rude awakening for the political elite in low-income and middle-income countries". BMJ Global Health. 2020;5(7):e003063.

22. Secretaría de Gestión de Riesgos. Situación nacional por COVID19. No. 151. 2020; June 10. Available at: https:/ / www.gestion deriesgos.
gob.ec/wp-content/uploads/2020/07/INFOGRAFIA-NACIONALCOVI-19-COE-NACIONAL-08h00-27072020.pdf

Manuscript (original in Spanish) received on 30 April 2020. Revised version accepted for publication on 10 August 2020.

\section{Sostenibilidad en la prevención de enfermedades crónicas: lecciones del programa Salud al Paso en Ecuador}

RESUMEN El presente estudio analiza las condiciones y posibilidades de permanencia del programa Salud al Paso de la Secretaría Metropolitana de Salud del Municipio de Quito, Ecuador, como ejemplo para iniciativas similares, en el contexto de los cambios efectuados por la nueva administración en mayo del 2019. El análisis de esta implementación enfocada en la prevención de enfermedades no transmisibles se centró en la base de datos de usuarios del programa, la información recabada desde las perspectivas del personal operativo, el conocimiento del programa y el posicionamiento de líderes locales y de opinión del Distrito Metropolitano de Quito, así como información oficial. Con base en estos datos, el estudio identificó factores que podrían haber facilitado u obstaculizado su permanencia y documentó la fundamentación de las nuevas autoridades para suspender las actividades de libre demanda propias del programa y limitar la atención a las poblaciones bajo responsabilidad municipal (guarderías, escuelas y colegios, mercados, programas de atención a la tercera edad y empleados) y de pacientes con riesgo cardiometabólico identificado. La institucionalización insuficiente del programa, concebido más como proyecto y con una también insuficiente visión de permanencia en el tiempo, fue mencionada como un posible obstáculo por líderes y personal operativo. La prevalencia creciente de enfermedades no transmisibles demanda iniciativas para su prevención, que deben institucionalizarse para asegurar su continuidad y superar eventuales cambios de gobierno. Además, intervenciones futuras semejantes a Salud al Paso deberán establecer una mejor articulación sectorial, en especial con el Ministerio de Salud Pública y otras redes de servicios.

Palabras clave Política pública; servicios preventivos de salud; enfermedades no transmisibles; gestión en salud; Ecuador. 